\title{
Toxicity and Viral Load in Urine during Valganciclovir Therapy in Premature Infants
}

\author{
Merel Boesveld, Henrica L. M. Van Straaten, Marieke A. C. Hemels \\ Department of Neonatology, Isala, Zwolle, Netherlands \\ Email:m.a.c.hemels@isala.nl
}

How to cite this paper: Boesveld, M., Van Straaten, H.L.M. and Hemels, M.A.C. (2017) Toxicity and Viral Load in Urine during Valganciclovir Therapy in Premature Infants. Pharmacology \& Pharmacy, 8, 275-282.

https://doi.org/10.4236/pp.2017.88020

Received: July 4, 2017

Accepted: August 27, 2017

Published: August 30, 2017

Copyright $\odot 2017$ by authors and Scientific Research Publishing Inc. This work is licensed under the Creative Commons Attribution International License (CC BY 4.0).

http://creativecommons.org/licenses/by/4.0/

\begin{abstract}
Cytomegalovirus (CMV) infection is the most important cause of mental retardation and sensorineural hearing loss. Antiviral treatment with valganciclovir, a relatively new but potential toxic oral drug, is recommended to prevent further hearing deterioration. In this retrospective cohort study we evaluated the relation between the dose of valganciclovir and the reduction of CMV viral load, as well as the toxicity. All neonates with gestational age $<32$ weeks with CMV infection treated with oral valganciclovir $(30 \mathrm{mg} / \mathrm{kg} /$ day $)$ were included. Time interval to reach CMV viral load below detection level $(<250$ copies $/ \mathrm{ml}$ ) was determined. Toxicity was measured by plasma trough levels, thrombocytopenia and leukopenia. Data of 6 infants, median gestational age 252 weeks, were analyzed. Time interval between start of therapy and viral load below detection level was 25 - 54 days. In total, 37 through plasma samples were analyzed. Of these, 28 were in the normal range, 3 above and 6 under the target concentration. Mild transient leukopenia occurred in 1 infant. No thrombocytopenia occurred. Conclusion: Antiviral treatment of $\mathrm{CMV}$ infection with oral valganciclovir results in adequate plasma through levels. Also, a progressive reduction of viral load in the urine below detection level was reached within 25 - 54 days, without serious short time side effects.
\end{abstract}

\section{Keywords}

CMV, Premature Infants, Valganciclovir, Treatment

\section{Introduction}

Cytomegalovirus (CMV) is a consistent infection worldwide. In adults it is an innocuous infection; in neonates it is an important cause of neonatal morbidity. CMV infection is the most important cause of mental retardation and sensori- 
neural hearing loss [1] [2] [3] [4]. Therefore, antiviral treatment is recommended in selective cases; several small studies support preventive treatment with intravenous administered ganciclovir for further hearing deteriorations. However, this treatment requires long term hospitalization and withholds a reliable risk of catheter-associated infection. A relatively new drug for the treatment of $\mathrm{CMV}$ infection in neonates is oral valganciclovir. Valganciclovir is a prodrug of ganciclovir with high oral bioavailability and therefore a good alternative to ganciclovir [4] [5] [6] [7] [8]. Currently, there is great variation in dose (30 - 56 $\mathrm{mg} / \mathrm{kg} /$ day) and duration of treatment (between 6 weeks and 6 months) and limited information about the relationship with the viral load and toxicity in premature infants [4] [5] [7] [9] [10]. The viral load of CMV can be detected in blood or urine by DNA-polymerase chain reaction (PCR). Boppana et al. [11] and Lanari et al. [12] already demonstrated that a high viral load, as a reflection of high virus activity, is associated with neuro sensorineural hearing loss. Without treatment, children with congenital CMV continue to excrete the virus in the urine for approximately 3 - 5 years [7]. Valganciclovir, has the risk of serious toxic side effects including thrombocytopenia and leukocytopenia, therefore determining plasma levels are recommended [7].

In this study we evaluated the relation between the dose of oral valganciclovir and the reduction of CMV viral load over time in the urine, as well as the toxicity, determined as high valganciclovir plasma trough levels and neutropenia or thrombocytopenia, in infants with a gestational age $<32$ weeks.

\section{Materials and Methods}

We performed a retrospective cohort study in our neonatal intensive care unit (NICU) of the Isala in Zwolle, the Netherlands. Data were collected from January 2005 until December 2013.

\subsection{Subjects}

All neonates $<32$ weeks gestational age treated with oral valganciclovir for CMV infection were included. The diagnosis of CMV was based on a positive urine culture. Exclusion criteria were: congenital anomalies and incomplete data.

Due to our tertiary function, neonates were referred to a general hospital after a gestational age of 32 weeks. Information on follow-up was required from the pediatricians by questionnaires. We recorded the following characteristics: gestational age at delivery, mode of delivery, birth weight, gender, clinical symptoms (included intra-uterine growth restriction, microcephaly, hepatitis, hepatosplenomegaly, petechiae, thrombocytopenia, pneumonitis and chorioretinitis), cerebral anomalies (lenticulostriate vasculopathy and/or germinolytic cysts on cerebral ultrasound), abnormal hearing test, indication for treatment, postnatal age at start of treatment, number of CMV-copies and duration of valganciclovir treatment. Time interval (days) to reach CMV viral load below detection level was determined. 


\subsection{Viral Load}

Number of CMV copies/ml were measured in the urine by DNA-realtime PCR (Applied Biosystems ABI 7500), with a ultimate detection level of $<250$ copies $/ \mathrm{ml}$.

\subsection{Valganciclovir}

The initial dosage of oral valganciclovir was $30 \mathrm{mg} / \mathrm{kg} /$ day divided in 2 doses, regularly adapted for weight gain and plasma levels. Before starting treatment and subsequently every week plasma levels of valganciclovir $\left(\mathrm{P}_{\text {trough }}\right.$ and $\left.\mathrm{P}_{\text {peak }}\right)$ and side effects of treatment such as thrombocytopenia $(<100 \times 109 / \mathrm{L})$ [13] and leukopenia $(<5 \times 109 / \mathrm{L})$ were determined in blood required by venous punction.

Platelets and the leukocytes were measured by Sysmex technology. Plasma samples for valganciclovir were obtained at steady state, just before the oral solution (Ptrough) and two hours after administration (Ppeak). The suggested therapeutic range for plasma levels are: Ptrough $0.2-1 \mathrm{mg} / \mathrm{L}$ and Ppeak 2.5 - 12.5 $\mathrm{mg} / \mathrm{L}$. Blood Samples were centrifuged and serum samples collected and tested immediately using liquod chromatography-mass spectrometry (LC-MS).

\subsection{Statistical Analysis}

Statistical analysis was performed using SPSS software version 22.0. Patient characteristics are described by number and percentage or expressed as median with interquartile range (IQR). The variable pharmacokinetic data is expressed as mean with standard deviation (SD) and median with IQR. The study was approved by the medical ethical committee of our hospital.

\section{Results}

During the study period 13 infants were diagnosed with a CMV infection and treated with oral valganciclovir. Seven of the 13 infants were excluded because of incomplete data about CMV load in urine. Finally six neonates, two infants with a congenital infection and four with a postnatal infection, were analyzed. The median gestational age was 264 weeks (IQR 251 - 284). Maternal and infant characteristics are shown in table 1. Five out of 6 infants had clinical symptoms of CMV infection consisting of intra-uterine growth restriction, hepatosplenomegaly and pneumonitis, the other infant showed only lenticulostriate vasculopathy, a neurologic involvement established on cerebral ultrasound scans in combination with a very high viral urine load and a gestational age $<32$ weeks. During treatment 4 out of 6 infants finally were negative for CMV isolation in urine; the time interval between the start of valganciclovir and the moment CMV viral load dropped below detection level was 25 - 54 days (median 48 days). The others demonstrated more than $99 \%$ decrease of CMV viral load, but not below detection level (Figure 1). Total duration of treatment varied between six weeks and six months (Table 1). Valganciclovir plasma levels were measured regularly (Table 2). In total, 37 trough plasma samples and $2 \mathrm{~h}$ plasma samples 


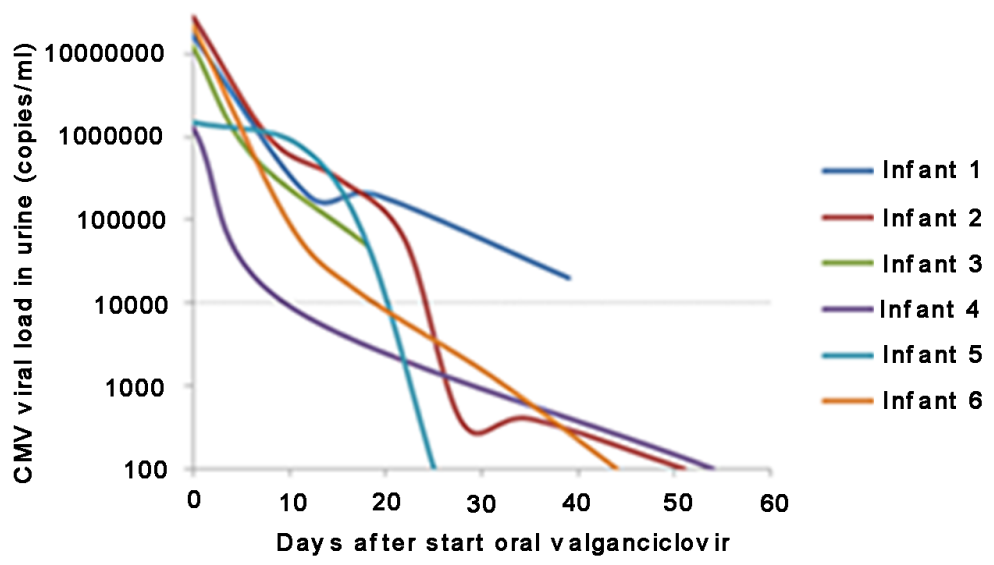

Figure 1. CMV viral load in time after start therapy with oral valganciclovir.

Table 1. Baseline table of infants treated with oral valganciclovir for CMV infection.

\begin{tabular}{ccc}
\hline Characteristics & Congenital CMV infection & Postnatal CMV infection \\
$\mathbf{N}=\mathbf{N}=\mathbf{4}$
\end{tabular}

Data are expressed as number (\%) or median (IQR- interquartile range).

Table 2. Valganciclovir plasma levels $\left(\mathrm{P}_{\text {trough }}\right.$ and $\left.\mathrm{P}_{\text {peak }}\right)$ of all six infants with CMV infection.

\begin{tabular}{lcccc}
\hline & $\begin{array}{c}\text { Median Ptrough } \\
(\mathrm{IQR})\end{array}$ & $\begin{array}{c}\text { Mean Ptrough } \\
( \pm 1 \mathrm{SD})\end{array}$ & $\begin{array}{c}\text { Median Ppea } \\
(\mathrm{IQR})\end{array}$ & $\begin{array}{c}\text { Mean Ppeak } \\
( \pm 1 \mathrm{SD})\end{array}$ \\
\hline Patient 1 & $0.7(0.5-2.3)$ & $1.3(1.0)$ & $3.5(1.8-7.5)$ & $4.4(2.9)$ \\
Patient 2 & $0.8(0.6-2.8)$ & $1.5(1.7)$ & $4.9(3.6-13.0)$ & $7.6(7.0)$ \\
Patient 3 & $1.0(0.4-1.2)$ & $0.8(0.4)$ & $3.2(2.3-4.5)$ & $3.7(1.9)$ \\
Patient 4 & $0.5(0.5-0.5)$ & $0.5(0.15)$ & $3.1(1.8-4.3)$ & $3.1(1.5)$ \\
Patient 5 & $0.5(0.5-0.5)$ & $0.5(0.0)$ & $3.7(3.7-5.1)$ & $3.8(1.3)$ \\
Patient 6 & $0.2(0.1-0.4)$ & $0.3(0.2)$ & $3.0(2.5-3.7)$ & $3.1(0.7)$
\end{tabular}

Ptrough: plasma level just before the administration of valganciclovir; Ppeak: plasma level two hours after administration of valganciclovir. 
were analyzed. Of these 37 trough samples, 28 were in the normal range, 3 above and 6 under the target concentration. Mean $P_{\text {trough }}$ concentration was $0.8 \mu \mathrm{g} / \mathrm{ml}$ $\left( \pm 1 \mathrm{SD} 0.8 \mu \mathrm{g} / \mathrm{ml}\right.$ ) and median $\mathrm{P}_{\text {trough }}$ concentration was $0.5 \mu \mathrm{g} / \mathrm{ml}$ (IQR: 0.4 $0.9)$. Mean $P_{\text {peak }}$ concentration was $4.2 \mu \mathrm{g} / \mathrm{ml}( \pm 1$ SD $3.2 \mu \mathrm{g} / \mathrm{ml})$ and median $P_{\text {peak }}$ concentration was $3.5 \mu \mathrm{g} / \mathrm{ml}$ (IQR: 2.5 - 4.9). No thrombocytopenia occurred. Mild leukopenia (leukocytes $4.5 \times 109 / \mathrm{L}$ ) occurred in one infant.

\section{Discussion}

This study demonstrates that treatment of CMV infection with oral valganciclovir with a dosage of $30 \mathrm{mg} / \mathrm{kg}$ in premature infants $<32$ weeks gestational age results in adequate plasma through levels. Also, a progressive reduction of viral load in the urine below detection level was reached within 25 - 54 days, without serious short time side effects. Great variation in dosage of oral valganciclovir, from $30-56 \mathrm{mg} / \mathrm{kg} /$ day, is described in the literature [4] [5] [7] [9] [10], however, all performed in infants with a gestational age $\geq 32$ weeks. Our own results support the safety of oral valganciclovir in a dosage of $30 \mathrm{mg} / \mathrm{kg} /$ day in infants $<32$ weeks gestational age, either in congenital or postnatal CMV infection. Except for one infant with transient marginal leukopenia, no toxicity was found. This is important while considering the possibility of expanding the criteria and the duration of treatment with valganciclovir in very premature neonates.

In 2005 Boppana et al. [11] stated that infants with $<5 \times 103 \mathrm{pfu} / \mathrm{mL}$ of urine $\mathrm{CMV}$ and infants with $<1 \times 104$ copies/mL of viral DNA in blood plasma were at a lower risk for hearing loss. The study of Lanari et al. [12] showed a negative predictive value of $95 \%$ of progressive hearing loss in patients with DNA emia $<1000$ copies per 105 PMNLs. Recently, Forner et al. [14], described that infants with a viral load in blood at birth of $\geq 12,000$ copies/mL were more likely to experience CMV-related sequelae and that the risk of hearing deficit increased with a viral load in blood of $\geq 17,000$ copies/mL. Rivera et al. [15] concluded that infants with urine viral load $>50,000 \mathrm{pfu} / \mathrm{ml}$ were at greater risk of hearing loss. Determination of the presumed therapeutic level in urine and blood is an important subject for further research, as well as the target time to decrease the viral load. One can hypothesis that a shorter period of high viral load might reduce the risk of vulnerability of the neonatal brain during a developmental period of rapid cerebral growth regarding volume and connectivity. There is no strong relationship between blood levels of valganciclovir and rate of viral clearance. Besides, antiviral cellular immunity plays an essential role in viral clearance. More research is necessary to determine the dose effect and viral clearance after valganciclovir in very premature infants. In the literature there's agreement to start antiviral treatment in infants with a symptomatic congenital CMV disease [16], but treatment of asymptomatic congenital or postnatal CMV is still controversial and under debate. Nevertheless, $7.2 \%-21 \%$ infants with an asymptomatic congenital infection will have permanent sequelae, predominantly sensorineural hearing loss [1] [2] [4] [12] [17]. In addition, in premature infants $<32$ weeks of age a postnatal CMV infection, mostly acquired by breast milk, can result in se- 
vere postnatal acquired symptomatic disease [18] [19] [20]. An additional risk of sensorineural hearing loss in this group has not been excluded. Regarding their cerebral developmental stage a postnatal CMV infection in very premature infants shortly after birth might not be unharmful and might face the same consequences as a fetal CMV infection in the second trimester of pregnancy. Based on this assumption and the reported low toxicity of oral valganciclovir, furthermore research might give insight in the potential of valganciclovir treatment in very premature infants with early postnatal infection in relation to the trend of viral load in plasma or urine. Finally, the duration of treatment should be noticed. In the literature most infants are being treated for six weeks [7] [9] [10], however treatment up to six months is considered in infants with moderately to severe congenital CMV in recent consensus recommendations [4] [21]. In our opinion, the duration of therapy is also dependent on the natural defenses to curb the virus replication or upon the end of the vulnerable period. In this study most infants were treated for 3 months, with a variation between 6 weeks and 6 months. At first, the duration was chosen to gap a vulnerable period of cerebral development and secondly based on the well tolerance of the oral valganciclovir. Both are open for discussion and subject for further research. This study has some limitations to be addressed. At first, it is the small sample size of this single centre study. Furthermore, due to the focus on pharmacotherapeutic issues only short term follow up has been incorporated.

\section{Conclusion}

In this study, we showed that antiviral treatment with oral valganciclovir in case of congenital or postnatal acquired CMV infection is safe, even for premature neonates with gestational age $<32$ weeks. Viral load may be used to measure the pharmacological effectiveness of treatment. Therefore, an extension of the treatment period towards 6 months may safely be introduced while closely monitoring blood parameters and viral load. Future prospective studies evaluating the effect of different dosage regimens on the decrease of viral load and the long term outcome are recommended, also in premature infants treated for CMV infection.

\section{References}

[1] Goderis, J., De Leenheer, E., Smets, K., van Hoecke, H., Keymeulen, A. and Dhooge, I. (2014) Hearing Loss and Congenital CMV Infection: A Systematic Review. Pediatrics, 134, 972-982. https://doi.org/10.1542/peds.2014-1173

[2] Fowler, K.B. and Boppana, S.B. (2006) Congenital Cytomegalovirus (CMV) Infection and Hearing Deficit. Journal of Clinical Virology, 35, 226-231. https://doi.org/10.1016/j.jcv.2005.09.016

[3] Rosenthal, L.S., Fowler, K.B., Boppana, S.B., Britt, W.J., Pass, R.F., Schmid, S.D., et al. (2009) Cytomegalovirus Shedding and Delayed Sensorineural Hearing Loss: Results from Longitudinal Follow-Up of Children with Congenital Infection. The Pediatric Infectious Disease Journal, 28, 515-520. https://doi.org/10.1097/INF.0b013e318198c724 
[4] Lombardi, G., Garofoli, F. and Stronati, M. (2010) Congenital Cytomegalovirus Infection: Treatment, Sequelae and Follow-Up. The Journal of Maternal-Fetal \& Neonatal Medicine, 23, 45-48. https://doi.org/10.3109/14767058.2010.506753

[5] Meine Jansen, C.F., Toet, M.C., Rademaker, C.M.A., Ververs, T.F.F., Gerards, L.J. and van Loon, A.M. (2005) Treatment of Symptomatic Congenital Cytomegalovirus Infection with Valganciclovir. Journal of Perinatal Medicine, 33, 364-366. https://doi.org/10.1515/JPM.2005.065

[6] Amir, J., Wolf, D.G. and Levy, I. (2010) Treatment of Symptomatic Congenital Cytomegalovirus Infection with Intravenous Ganciclovir Followed by Long-Term Oral Valganciclovir. European Journal of Pediatrics, 169, 1061-1067. https://doi.org/10.1007/s00431-010-1176-9

[7] Kimberlin, D.W., Acosta, E.P., Sánches, P.J., Sood, S., Agrawal, V., Homans, J., et al. (2008) Pharmacokinetic and Pharmacodynamics Assessment of Oral Valganciclovir in the Treatment of Symptomatic Congenital Cytomegalovirus Disease. The Journal of Infectious Diseases, 197, 836-845. https://doi.org/10.1086/528376

[8] Stronati, M., Lombardi, G., Garofoli, F., Villani, P. and Regazzi, M. (2013) Pharmacokinetics, Pharmacodynamics and Clinical Use of Valganciclovir in Newborns with Symptomatic Congenital Cytomegalovirus Infection. Current Drug Metabolism, 14, 208-215.

[9] Galli, L., Novelli, A., Chiappini, E., Gervaso, P., Cassetta, M.I., Fallani, S. and de Martino, M. (2007) Valganciclovir for Congenital CMV Infection: A Pilot Study on Plasma Concentration in Newborns and Infants. The Pediatric Infectious Disease Journal, 26, 451-453. https://doi.org/10.1097/01.inf.0000261111.90075.4d

[10] Lombardi, G., Garofoli, F., Villani, P., Tizzoni, M., Angelini, M., Cusato, M., et al. (2009) Oral Valganciclovir Treatment in Newborns with Symptomatic Congenital Cytomegalovirus Infection. European Journal of Clinical Microbiology \& Infectious Diseases, 28, 1465-1470. https://doi.org/10.1007/s10096-009-0806-5

[11] Boppana, S.B., Fowler, K.B., Pass, R.F., Rivera, L.B., Bradford, R.D., Lakeman, F.D. and Britt, W.J. (2005) Congenital Cytomegalovirus Infection: Association between Virus Burden in Infancy and Hearing Loss. Journal of Pediatrics, 146, 817-823.

[12] Lanari, M., Lazzarotto, T., Venturi, V., Papa, I., Gabrielli, L., Guerra, B., et al. (2006) Neonatal Cytomegalovirus Blood Load and Risk of Sequelae in Symptomatic and Asymptomatic Congenitally Infected Newborns. Pediatrics, 117, e76-e83. https://doi.org/10.1542/peds.2005-0629

[13] Gill, F.M. (1983) Thrombocytopenia in the Newborn. Seminars in Perinatology, 7, 201-212.

[14] Forner, G., Abate, D., Mengoli, C., Palù, G. and Gussetti, N. (2015) High Cytomegalovirus (CMV) DNAemia Predicts CMV Sequelae in Asymptomatic Congenitally Infected Newborns Born to Women with Primary Infection During Pregnancy. The Journal of Infectious Diseases, 212, 67-71. https://doi.org/10.1093/infdis/jiu627

[15] Rivera, L.B., Boppana, S.B., Fowler, K.B., Britt, W.J., Stagno, S. and Pass, R.F. (2002) Predictors of Hearing Loss in Children with Symptomatic Congenital Cytomegalovirus Infection. Pediatrics, 110, 762-767. https://doi.org/10.1542/peds.110.4.762

[16] Rawlinson, W.D., Boppana, S.B., Fowler, K.B., Kimberlin, D.W., Lazzarotto, T., Alain, S., et al. (2017) Congenital Cytomegalovirus Infection in Pregnancy and the Neonate: Consensus Recommendations for Prevention, Diagnosis, and Therapy. The Lancet Infectious Diseases, 17, e177-e188.

[17] Dollard, S.C., Grosse, S.D. and Ross, D.S. (2007) New Estimates of the Prevalence of Neurological and Sensory Sequelae and Mortality Associated with Congenital Cy- 
tomegalovirus Infection. Reviews in Medical Virology, 17, 355-363.

https://doi.org/10.1002/rmv.544

[18] Lombardi, G., Garofoli, F., Manzoni, P. and Stronati, M. (2012) Breast Milk-Acquired Cytomegalovirus Infection in Very Low Birth Weight Infants. The Journal of Maternal-Fetal \& Neonatal Medicine, 25, 57-62.

https://doi.org/10.3109/14767058.2012.712345

[19] Narvaez-Arzate, R.V., Olguin-Mexquitic, L., Lima-Roge, L.V., Noyola, D.E., Barrios-Compaen, L.M. and Villegas-Alvarez, C. (2013) Cytomegalovirus Infection in Infants Admitted to a Neonatal Intensive Care Unit. The Journal of Maternal-Fetal \& Neonatal Medicine, 26, 1103-1106. https://doi.org/10.3109/14767058.2013.770459

[20] Turner, K.M., Lee, H.C., Boppana, S.B., Carlo, W.A. and Randolph, D.A. (2014) Incidence and Impact of CMV Infection in Very Low Birth Weight Infants. Pediatrics, 133, 609-615. https://doi.org/10.1542/peds.2013-2217

[21] Kimberlin, D.W., Jester, P.M., Sánchez, P.J., Ahmed, A., Arav-Boger, R., Michaels, M.G., et al. (2015) Valganciclovir for Symptomatic Congenital Cytomegalovirus Disease. The New England Journal of Medicine, 372, 933-943.

https://doi.org/10.1056/NEJMoa1404599

Submit or recommend next manuscript to SCIRP and we will provide best service for you:

Accepting pre-submission inquiries through Email, Facebook, LinkedIn, Twitter, etc. A wide selection of journals (inclusive of 9 subjects, more than 200 journals)

Providing 24-hour high-quality service

User-friendly online submission system

Fair and swift peer-review system

Efficient typesetting and proofreading procedure

Display of the result of downloads and visits, as well as the number of cited articles

Maximum dissemination of your research work

Submit your manuscript at: http://papersubmission.scirp.org/

Or contact pp@scirp.org 